\title{
KEBIJAKAN PEMERINTAH DALAM AKTUALISASI PANCASILA MELALUI MEDIA SOSIAL DITINJAU DARI PERSPEKTIF SOSIOLOGI KOMUNIKASI
}

\author{
Fuqoha $^{1}$, Indrianti Azhar Firdausi ${ }^{1}$ \\ ${ }^{1}$ Fakultas Ilmu Sosial, Ilmu Politik dan Ilmu Hukum, Universitas Serang Raya
}

\begin{abstract}
Pancasila is the philosophy of the Indonesian State as an idiil foundation of Indonesia people. As a State of law, Indonesia has actualized Pancasila in the State's legal system which is the basis for actuallity and achieving the ideals of the nation. The actualization of Pancasila is not sufficiently implemented in the legal order of the State, but must be actualized to each individual as a citizen of the soul value of Pancasila. Social media as a forum to actualize Pancasila for every Indonesian citizen. Through the sociology of communication approach, the actualization of Pancasila through social media can move and foster harmonization in social relations in accordance with the values of Pancasila.
\end{abstract}

Keywords: Actualization, Social Media, Sociology of Communication.

\section{Pendahuluan}

Konsepsi Negara hukum Indonesia memberikan kedudukan pancasila sebagai landasaan idiil dalam bernegara. Pancasila ialah ideologi Negara Indonesia yang tersusun dari nilai-nilai bangsa yang dirumuskan sebagai cita-cita berbangsa dan bernegara. Dalam sudut pandang filosofis, Pancasila adalah pandangan hidup dan/atau falsafah hidup berbangsa dan bernegara yang tersusun dalam 5 (lima) landasan dasar dan/atau esensi hidup bernegara. Konstitusi Negara Indonesia telah menguraikan bahwa Negara Indonesia adalah Negara hukum yang berarti penyelenggaraan Negara didasarkan pada aturan-aturan hukum. Sebagai
Negara hukum, maka sistem hukum yang diterapkan oleh Negara harus mencerminkan nilai-nilai bangsa Indonesia yang menjadi cita-cita dan tujuan bangsa dan Negara. Oleh karena itu, konsepsi Negara hukum Indonesia menempatkan pancasila sebagai landasan hukum tertinggi yang tertuang dalam alenia ke-4 pembukaan undang-undang dasar 1945.

Pancasila sebagai pandangan hidup berbangsa dan bernegara tidak dapat dirumuskan dalam peraturanperaturan hukum sebagai instrument penyelenggaraan Negara. Akan tetapi, rumusan pancasila harus dipahami oleh segenap warga Negara Indonesia sebagai pedoman dalam berperilaku baik bagi kepentingan individu 
maupun hubungan sosial sesama bangsa Indonesia maupun bangsa asing, Dengan demikian, peran pancasila dalam menjaga kehidupan berbangsa dan bernegara menjadi sangat esensial terlepas dari keberadaan hukum yang mengatur hubungan berbangsa dan bernegara.

Nilai-nilai pancasila harus diaktualisasikan pada tatanan perilaku dalam hubungan sosial di masyarakat. Oleh karenaitu, aktualisasi Pancasila menjadi instrumen dalam mewujudkan citacita dan tujuan bangsa yang harus dipahami oleh seluruh rakyat bangsa Indonesia serta menjadi tanggungjawab bersama dalam mewujudkan Negara hukum di Indonesia. Aktualisasi merujuk pada mengaktualkan, mewujudkan, mengimplementasikan nilai-nilai pancasila dalam kehidupan pribadi dan kehidupan sosial. (Syarbaini, 2001:122) Pada prinsip penyelenggaraan Negara Indonesia telah mengaktualkan pancasila dalam sistem hukum Negara. Hal tersebut dituangkan dalam ketentuan perundang-undangan tentang pemebentukan peraturan perundangundangan yang menempatkan pancasila sebagai landasan paling dasar dalam penyusunan dan pembentukan peraturan perundangundangan di Indonesia. Hubungan sosial masyarakat dipengaruhi oleh pola komunikasi antar warga yang pada akhirnya menciptakan perilaku sosial di masyarakat. Perilaku yang tumbuh dan berkembang tersebut menjadi tolak ukur aktualisasi pancasila dalam kehidupan berbangsa dan bernegara.

Dinamika kehidupan sosial bermasyarakat saat ini tidak terlepas dari revolusi industri 4.0 yang mengakibatkan pola hubungan sosial bermasyarakat yang dipengaruhi oleh teknologi informasi. Perkembangan teknologi informasi yang semakin pesat berimplikasi pada pengaktualisasian nilai-nilai pancasila pada setiap individu sebagai warga Negara Indonesia mengalami perubahan. Hal tersebut dapat menjadi sebuah tantangan sekaligus ancaman terhadap aktulisasi pancasila dalam kehidupan berbangsa dan bernegara. Di era teknologi informasi disebut juga sebaga era digital pola hubungan masyarakat dan komunikasi masyarakat beralih menggunakan media digital dan/atau media sosial sebagai alat berinteraksi. Era digital menciptakan perubahan kondisi sosial masyarakat yang menjadikan media sosial sebagai alat komunikasi massa. Penggunaan media sosial yang sangat massif oleh masyarakat menggambarkan pola hubungan sosial telah beralih secara langsung menuju arah digital.

Komunikasi di era digital saat ini tidak menjadikan seminar dan/atau dialog publik sebagai media untuk menjelaskan nilai-nilai pancasila. Teknologi informasi yang semakin canggih menghadirkan media baru (new media) dalam berkomunikasi, sehingga 
memudahkan setiap orang dan/atau penyelenggara Negara untuk saling berinteraksi satu dengan yang lain. Komunikasi massa menggunakan media sosial tentu memberikan warna berbeda dalam suatu komunikasi. Hal ini menjadi pembeda dimana dalam suatu seminar dan/atau dialog publik tidak semua orang memiliki kesempatan untuk memberikan tanggapan terhadap ide dan gagasan. Namun melalui teknologi digital sebagai sarana komunikasi, maka setiap orang dapat langsung memberikan respon terhadap persoalan yang sedang dipersoalkan dimasyarakat.

Persoalan yang dihadapi saat ini adalah mengaktualisasikan nilainilai pancasila sebagai landasaan idiil seiring perubahan pola komunikasi menggunakan media digital atau media sosial. Media sosial memberikan kemudahan dalam berkomunikasi mengenai aktulisasi pancasila, disisi lain media sosial dapat berubah menjadi penghalang upaya aktualisasi pancasila itu sendiri manakala muncul sudut pandang yang heteronom dalam menafsirkan pancasila. Perbedaan sudut pandang merupakan hal yang biasa dalam komunikasi, akan tetapi komunikasi yang baik adalah komunikasi yang mampu menciptakan ruang diskusi yang menyatukan pemikiran dan menerima perbedaan gagasan. Dalam komunikasi dikenal istilah sosiologi komunikasi yang berhubungan dengan proses saling mempengaruhi baik antarindividu maupun antara individu dengan kelompok. (Bungin, 2014:31)

Dari uraian diatas, peneliti ingin menguaraikan pola komunikasi dalam aktuliasasi pancasila melalui media sosial sebagai upaya mewujudkan masyarakat yang pancasilais. Media sosial dapat menjadi alat komunikasi yang mempengaruhi masyarakat secara luas di era teknologi informasi saat ini. Akan tetapi, media sosial pula dapat menjadi ancaman disharmonisasi hubungan sosial dalam mewujudkan cita-cita bangsa. Dengan demikian, aktualisasi pancasila harus lebih substantif menyentuh individu warga Negara, salah satunya menggunakan pendekatan sosiologi komunikasi.

\section{Metode Penelitian}

Penelitian ini merupakan model penelitian kualitatif yang bersifat deskriptif analitis, dengan maksud mengumpulkan data selengkap mungkin untuk menggambarkan fakta-fakta secara sistematis dan terintegrasi melalui data primer maupun data sekunder. (Soekanto, 1986:9) Penelitian ini mempelajari secara intensif suatu fenomena, latar belakang, interaksi sosial hingga dampak yang ditimbulkan. Kemudian, dalam penelitian ini analisis yang digunakan yakni pendektan studi kepustakaan melalui buku, jurnal dan berita dari sumber online sebagai bahan sekunder. 


\section{Analisis Dan Pembahasan}

\section{a. Perkembangan Komunikasi Massa menuju New Media}

Sejak awal abad 20 media massa telah mengalami perubahan yang signifikan, hal tersebut dapat terlihat dari pergeseran teknologi sehingga terdampak pada perubahan sosial, ekonomi dan budaya masyarakat secara massif. Pada era saat ini adanya pergeseran budaya

bersamaan berkembangnya teknologi yang disebut media baru. Media baru disebut sebagai prangkat teknologi komunikasi yang berbagi ciri yang sama dimungkinkan dengan digitalisasai dan ketersediannyaa yang luas untuk penggunaan pribadi sebagai alat komunikasi. (McQuail, 2011:148)

Komunikasi massa identik dengan media lama namun dalam prosesnya tidak terbatas pada media massa yang telah mengalami penurunan minat meskipun media baru juga membawa aktivitas komunikasi massa. Munculnya media baru dilihat sebagai perlawanan terhadap komunikasi massa. Terdapat dua kekuatan di awal perubahan komunikasi massa menuju new media yaitu komunikasi satelit dan pemanfaatan komputer hal ini terletak pada proses digitalisasi yang memungkinkan segala bentuk informasi saling berbaur dalam bentuk yang berbeda. Kita telah melihat banyaknya surat kabar yang berpindah dalam bentuk digital. Seiring dengan teknologi berbasis komputer, terdapat pula berbagai inovasi yang mengubah aspek komunikasi, seperti alat baru penyiaran dengan kabel, satelit dan radio telah banyak meningkatkan kemampuan penyiaran. Bentukbentuk penyimpanan baru termasuk perekam video pribadi, CD-ROM, CD, DVD, iPod dan seterusnya yang kemungkinan dapat memperluas jaringan. Meskipun tidak langsung mendukung komunikasi massa, kemungkinan baru untuk pembuatan media secara pribadi (camcorder, komputer pribadi, printer, kamera, telepon genggam, dan lainnya) telah memperluas lingkungan media dan menjembatani antara komunikasi publik dan pribadi, serta antara ranah profesonal dan amatir. (McQuail, 2011:43)

Dampak bagi media massa bahwa media tradisional mendapat keuntungan dari inovasi media baru dan juga mendapat pesaing baru. Dampak kedua bahwa revolusi komunikasi telah secara umum mengubah keseimbangan kekuatan dari media kepada 
khalayak, dalam hal ini khalayak mendapat pilihan dan lebih aktif menggunakan media. Komunikasi massa tradisional pada intinya bersifat satu arah, sementara bentuk baru komunikasi intinya adalah interaktif. Komunikasi massa memiliki beberapa hal sebelum menjadi massal dan tersentralisasi. (McQuail, 2011:43-44)

Hubungan antara media dan masyarakat memiliki dimensi material, politik dan normatif atau sosio-kultural. Pada dasarnya, semua media komunikasi publik memiliki potensi menyimpang dari sistem kontrol sosial, meskipun demikian perkembangan kelembagaan dari media massa yang sukses biasanya berujung pada hilangnya potensi penyimpangan awal, sebagian karena efek dari komersialisasi, sebagian lagi kekuasaan masyarakat. Pada dimensi normatif terdapat pembatasan yang cukup luas diterapkan pada televisi karena akar budaya dna moral yang sama, media ini adalah media yang populer dan memiliki dampak emosional kuat terhadap khalayak sehingga perlu diawasi menurut "kepentingan publik". (McQuail, 2011:46)

Media digital dengan media massa dibedakan atas dasar derajat interaktivitas.
Semakin interaktif media memungkinkan adanya integrasi motivasi dan peningkatan respons dari pengguna. Inter-aktivitas telah dibangun dari potensi reaksi sederhana terhadap penciptaan dan distribusi konten, sama seperti situs jejaring sosial. (McQuail, 2011:49-50) Perbedaan antara media personal dan media massa adalah keterlibatan pengguna, dimana media personal lebih simetris dan berperan aktif baik sebagai penerima maupun sebagai produsen. (McQuail, 2011:149]

b. Peran Media Sosial sebagai Sarana Aktualisasi Pancasila

Suatu masyarakat dapat terbentuk dan/atau diubah melalui suatu tindakan dan interaksi manusia, bahwa hubungan sosial masyarakat dipengaruhi oleh simbol yang universal yaitu pandangan hidup, legitimasi pranata sosial serta pemberi makna dalam berbagai bidang kehidupan. (Bungin, 2008:7) Dalam kehidupan berbangsa dan bernegara sesuai amanat kontitusi negara Indonesia, maka simbol kehidupan bagi bangsa dan Negara Indonesia yaitu pancasila. Pancasila sebagai falsafah dan pandangan hidup yang mesti tumbuh bagi setiap warga Negara Indonesia. 


\section{Interaksi}

dalam

hubungan sosial masyarakat tidak terlepas dari peran komunikasi. Komunikasi dewasa ini dipengaruhi oleh kemajuan teknologi informasi yang menyediakan sarana digital komunikasi. Era digital dengan perkembangan teknologi informasi yang semakin berkembang mengubah pola komunikasi bagi setiap orang sehingga dapat berkomunikasi melalui saluransaluran yang tersedia. Media sosial merupakan salah satu instrumen dari lahirnya perkembangan teknologi yang menghubungkan setiap orang, masyarakat hingga institusi/organisasi dapat menjalin komunikasi yang efektif dan efisien.

Media sosial saat ini dianggap sebagai alat komunikasi yang efektif dan efisien serta digunakan hampir seluruh masyarakat sehingga dapat memberikan pengaruh pada masyarakat. Pengaruh tersebut oleh Berger dan Luckmann sebagai dialektika yaitu proses eksternalisasi, objektivasi dan internalisasi. Proses tersebut merupakan bagian dari kontruksi sosial kehidupan dengan menawarkan konsep, kesadaran umum hingga wacana publik. (Bungin, 2008:7) $\begin{array}{rr}\text { Aktualisasi } & \begin{array}{r}\text { pancasila } \\ \text { kehidupan }\end{array}\end{array}$ bermasyarakat, berbangsa dan bernegara dapat dilakukan dengan dua pendekatan secara objektif dan secara subjektif. Aktualisasi pancasila secara obyektif, menjadikan pancasila sebagai landasan idiil dan materil dalam setiap aspek penyelenggaraan Negara yang berarti setiap perbuatan dan/atau tindakan pemerintah dan rakyat dalam konsepsi Negara hukum harus tunduk dan patuh pada nilai-nilai tersebut. Sedangkan aktualisasi pancasila secara subjektif sangat ditentukan oleh kesadaran, ketaatan, serta kesiapan individu untuk mengamalkan pancasila. Sikap dan tingkah laku seseorang sangat menentukan terlaksananya nilai-nilai pancasila dalam segala aspek kehidupan. (Syarbaini, 2001:122)

Pola aktualisasi pancasila yang diuraikan diatas tersirat peran komunikasi dalam bentuk pengolahan informasi, penyampaian informasi hingga penerimaan informasi dari masyarakat pada individu maupun individu pada masyarakat. Secara obyektif pancasila tersampaikan melalui kebijakan-kebijakan pemerintah baik dalam bentuk regelling atau beschiking. Pancasila 
merupakan sumber hukum tertinggi yang menjadikan sistem hukum Negara Indonesia tidak terlepas dari pengaktualisasian dari nilainilai pancasila. Sedangkan secara subyektif terdapat peran komunikasi bahwa aktualisasi pancasila dilakukan melalui komunikasi dua arah sehingga nilai-nilai pancasila dapat terlaksana dalam kehidupan berbangsa dan bernegara.

Komunikasi merupakan bagian dari interaksi sosial yang saling menginformasikan dan saling mempengaruhi dalam interaksi sosial tersebut. Ali Syamsuddin menguraikan bahwa tanpa komunikasi tidak akan terjadi interaksi sosial, tersampaikannya makna-makna dan nilai-nilai serta pranata sosial tidak akan teraktualisasikan. (Amin, 2014) Bahkan suatu pesan yang timbul dari komunikasi dalam interaksi sosial dapat menjadi sugesti bagi penerima yang dapat berkembang melalui proses identifikasi, simpati, dan imitasi bahkan dapat menimbulkan sikap antipati. (Amin, 2014)

Dinamika sosial yang berkembang saat ini adalah komunikasi yang berbasis teknologi informasi. Pola komunikasi yang terbangun seiring kemajuan teknologi informasi beralih pada digital komunikasi dan/atau media sosial sebagai saluran komunikasi yang memberikan kemudahan dalam berkomunikasi tanpa dibatasi oleh ruang dan waktu. Media sosial melalui berbagai saluran yang tersedia di era digital memberikan informasi yang disampaikan semakin cepat serta interaktif. Melalui media sosial penyebaran dan/atau penyampaian informasi semakin memudahkan pendistribusian informasi. (Fuqoha, Anggraini, \& Apipah, 2019) Implikasi dari penggunaan media sosial sangat beragam dalam interaksi sosial bermasyarakat baik dalam bentuk positif dengan terbentuknya hubungan sosial yang terbentuk dari faktor simpati dan/atau empati hingga dalam bentuk negatif karena sikap antipasti terhadap isu dan/atau peristiwa yang dikomunikasikan.

Aktualisasi nilai-nilai pancasila perlu ditanamkan pada setiap individu, tidak cukup hanya mengaktualisasi nilai-nilai pancasila dalam substansi sistem hukum Indonesia maupun pada peraturan-peraturan perundang-undangan semata. Bentuk aktualisasi pancasila di era digital mulai beralih pada penggunaan media sosial yang ditandai dengan gerakan media sosial melalui slogan "Saya 
Indonesia, Saya Pancasila". Gerakan media sosial tersebut merupakan inovasi dalam mengenalkan dan menanamkan nilai-nilai pancasila bagi masyarakat di era digital. Aktualisasi pancasila melalui media sosial tersebut diinisiasi oleh pemerintah dalam rangka memperingati hari lahir pancasila. Triawan Munaf mengatakan bahwa pancasila harus mengalir dalam darah dan detak jantung setiap orang Indonesia karena Pancasila mengajari kita untuk seragam dalam memahami keberagaman. (Rimadi, 2017 diakases pada 20/9/2019)

Dinamika yang dihadapi dalam upaya aktualisasi pancasila melalui media sosial adalah perwujudan nilai-nilai pancasila dalam kehidupan sehari-hari bukan sekedar rasa simpati bahwa pancasila merupakan simbol ideologi. Banyak masyarakat mengapresiasi dan bersimpati dengan slogan "Saya Indonesia, Saya Pancasila" dengan mengikuti dan/atau membagikan slogan sebagai bentuk dukungan dan menyatakan diri sebagai individu yang pancasila. Merujuk pendapat Ali Syamsuddin Amin maka slogan "Saya Indonesia, Saya Pancasila" merupakan suatu pesan yang dikomunikasikan dalam interaksi sosial berupa sugesti bagi penerimanya.

Jika ukuran terwujudnya nilai-nilai pancasila berdasarkan pada tersugestinya masyarakat dengan menyatakan diri "Saya Indonesia, Saya Pancasila" maka pancasila teraktualisasikan secara efektif dan efisien melalui media sosial. Hal tersebut dikarenakan banyaknya pengguna media sosial yang turus serta menggunakan slogan "Saya Indonesia, Saya Pancasila". Zulfan dan Gumilar dalam penelitiannya menguraikan bahwa media sosial memiliki peran penting dan memiliki keunggulan yang dapat digunakan dalam upaya penginformasian dan penarikan minat masyarakat. (Zulfan \& Gumilar, 2014)

Media sosial memberikan kemudahan dalam berkomunikasi mengenai aktulisasi pancasila, namun disisi lain media sosial dapat berubah menjadi ancaman aktualisasi pancasila itu sendiri ketika muncul sudut pandang atau persepsi aktualisasi pancasila di media sosial. Persepsi dapat diartikan sebagai proses pemaknaan terhadap suatu peristiwa atau fenomena sehingga manusia memperoleh pengetahuan baru dengan menyimpulkan informasi atau menafsirkan 
pesan. (Amin, 2014) Persepsi terhadap aktualisasi pancasila melalui media sosial dalam bentuk slogan "Saya Indonesia, Saya Pancasila" dapat berubah menjadi antipasti yang berarti komunikasi dalam ruang media sosial berimplikasi negatif.

Persepsi yang tercipta terhadap "Saya Indonesia, Saya Pancasila" adalah adanya pengguna media sosial yang menyatakan diri pancasilais namun dalam praktik kehidupan tidak sesuai dengan nilai-nilai pancasila. Implikasi dari kegagalan komunikasi massa melalui media sosial terhadap individu yang seolaholah pancasila dengan mengikuti slogan "Saya Indonesia, Saya Pancasila" adalah ketidakpercayaan masyarakat akan nilai-nilai pancasila itu sendiri. Burhan Bungin (Bungin, 2014:31) mengatakan bahwa dalam interaksi sosial tidak terlepas dari proses saling mempengaruhi baik antarindividu maupun antara individu dengan kelompok. Dimana proses tersebut akan berpengaruh pada objektivitas maupun subjektifitas yang dikomunikasikan.

\section{c. Media Sosial dalam Perspektif Sosiologi Komunikasi}

Media sosial merupakan bagian dari perkembangan teknologi komunikasi yang dikenal dengan istilah new media. Istilah new media menggambarkan kerakteristik sarana komunikasi atau media komunikasi yang berbeda dari yang ada sebelumnya. Media sosial memiliki muatan yang sangat interaktif sehingga didefinisikan sebagai sebuah media yang memberikan kemudahan bagi para pengguna dalam berinteraksi, menciptakan konten berita hingga berbagi informasi yang memiliki kekuatan sosial dalam mempengaruhi opini publik yang berkembang di masyarakat. (Watie, 2011:7071)

Keberadaan media sosial sebagai salah satu sarana komunikasi memiliki potensi pengaruh yang sangat luas. Penelitian Zulfan dan Gumilar tentang potensi media sosial mengungkapkan bahwa media sosial memiliki peran penting dan memiliki keunggulan yang dapat digunakan oleh komunitas dalam upaya pelestarian, penginformasian dan penarikan minat masyarakat. (Zulfan \& Gumilar, 2014) Berlandaskan hasil pemeikiran tersebut, maka masyarakat saat ini tidak terlepas dari penggunaan media sosial baik individu, kelompok maupun institusi pemerintahan dan swasta. 


$r$ Perkembangan teknologi
informasi yang ditandai
semakin tingginya pengguna
media sosial menunjukan
pentingnya media
era besial dalam
informasi. Hal tersebut
mengubah konstruksi sosial
mengenai masyarakat sebagai
sekelompok manusia yang
tinggal dalam lingkungan bersama menjadi masyarakat yang berinteraksi menggunakan jaringan internet yang dikenal dengan istilah masyarakat internet. Pengistilahan masyarakat internet, yang menunjukan bahwa internet di era teknologi informasi sebagai sarana penghubung dan komunikasi informasi yang dikenal dengan network society yang menandakan masyarakat di era teknologi informasi sangat dipengaruhi oleh media sosial. (Pratama \& Sadewo, 2015)

Era digital menciptakan perubahan kondisi sosial masyarakat yang menjadikan media sosial sebagai alat komunikasi massa. Penggunaan media sosial yang sangat massif oleh masyarakat mencirikan kebebasan berkomunikasi dan menyampaikan pendapat. Network society menjadi paradigma baru dalam komunikasi secara massif dalam mempengaruhi dan merekonstruksi perilaku sosial.
Pengaruh dapat timbul dari komunikasi antar-individu maupun antara individu dengan masyarakat dan/atau masyarakat terhadap individu. Perbedaan sudut pandang merupakan hal yang biasa dalam interaksi sosial, akan tetapi komunikasi yang baik adalah komunikasi yang mampu menciptakan ruang diskusi atau interaksi sosial yang menyatukan pemikiran dan menerima perbedaan gagasan. Interaksi sosial merupakan hubungan sosial yang dinamis yang mencakup hubungan orang perorangan, orang dengan kelompok dan kelompok dengan kelompok. (Soekanto, 2007:55) Interaksi sosial dapat terjadi dengan 2 (dua) syarat, pertama adanya kontak sosial (social contact) dan kedua, adanya komunikasi (communication). (Soekanto, 2007:58)

Dinamika sosial dalam interaksi sosial di era digital yang ditandai dengan new media merubah pola interaksi sosial dengan sarana teknologi informasi. Interaksi sosial saat ini lebih pada network society yang menjadikan pola social contact dari langsung menjadi tidak langsung. Penggunaan media sosial menjadikan ruang bagi social contact semakin sempit dan bahkan tanpa batas yang tidak mengharuskan 
kontak secara fisik. Dalam menjalin komunikasi (communication) dalam network society di era digital tidak terbatas pada komunikasi verbal, akan tetapi komunikasi dapat terbentuk dalam sebuah komunikasi tertulis hingga gambar sebagai ekspresi komunikasi.

Media sosial dalam pendekatan sosiologi komunikasi tidak merubah konstruksi komunikasi, akan tetapi memberikan ruang yang lebih terbuka dalam interaksi sosial. Media sosial memberikan masyarakat kemudahan dalam mengekspresikan ide dan gagasan dalam bentuk digital tidak terbatas pada substansi komunikasi. Media sosial sebagai salah satu bagian new media yang fungsinya berbentuk berinteraksi, bertukar informasi, dan mempublikasikan aktivitas sehari-harinya. Setiap interaksi mutlak membutuhkan sarana tertentu. Sarana menjadi medium simbolisasi dari apa yang dimaksudkan dalam sebuah interaksi. (Firdausi, 2018) Dalam media sosial suatu pesan yang timbul dari komunikasi dalam interaksi sosial yang memberikan sugesti bagi penerima dapat berupa pesan yang lebih estetis dengan penyertaan pesan bergambar. (Amin, 2014) $\begin{array}{rrr} & \text { Pemanfaatan } & \text { media } \\ \text { sosial } & \text { sebagai } & \text { sarana }\end{array}$ komunikasi di era new media harus dimaksimalkan oleh seluruh masyarakat. Salah satu yang harus diperhatikan yakni penggunaan media sosial secara bijak. kemudahan berkomunikasi yang ditawarkan dalam media sosial tidak berarti menjadikan media sosial sebagai alat untuk melakukan tindakan interaksi sosial yang bersifat negatif. Hal tersebut telah diungkapkan oleh Ali Syamsuddin Amin, (Amin, 2014) bahwa komunikasi melalui media sosial dapat menciptakan kondisi interaksi yang antipati atau bertentangan dengan kehendak komunikan.

Dengan demikian, interaksi sosial dalam aktualisasi pancasila melalui media sosial dapat menjadi imitasi, sugesti, identifikasi dan simpati. (Soekanto, 2007:57) Namun disisi lain suatu persepsi terhadap aktualisasi pancasila melalui media sosial dalam bentuk slogan "Saya Indonesia, Saya Pancasila" dapat berubah menjadi antipati yang berarti komunikasi dalam ruang media sosial berimplikasi negatif yang menciptakan ketidak percayaan network society terhadap interaksi sosial yang terjadi. 


\section{Kesimpulan}

Interaksi sosial sebagai bentuk konstruksi sosial di era digital menghadirkan perubahan dengan sarana-sarana interaksi yang berbasis teknologi. Komunikasi sebagai sarana interaksi sosial dengan new media menghadirkan media sosial sebagai salah satu sarana komunikasi yang lebih efisien di era teknologi informasi. Sehingga, saat ini masyarakat lebih dikenal dengan istilah network society yang merujuk pada masyarakat pengguna internet atau teknologi informasi sebagai sarana dalam berinteraksi sosial. Mewujudkan nilai-nilai pancasila dalam kehidupan berbangsa dan bernegara merupakan keharusan yang merupakan landasan dasar serta motivasi dalam berperilaku. Perwujudan nilai-nilai pancasila sebagai das sollen menuju das sein telah diaktualisasikan dalam berbagai bentuk secara objektif kedalam peraturan perundang-undangan hingga kebijakan-kebijakan politik pemerintahan. sedangkan secara subjektif melalui diskusi publik untuk menanamkan nilai-nilai pancasila dalam diri pribadi. Upaya aktualisasi pancasila di media sosial melalui slogan "Saya Indonesia, Saya Pancasila" merupakan upaya subyektif dalam mengenalkan pancasila pada masyarakat. Dalam sosiologi komunikasi, interkasi sosial dalam bentuk apapun baik menggunakan media sosial maupun secara konvensional akan saling mempengaruhi komunikan baik dalam bentuk sugesti yang diterima, maupun sugesti yang antipati dari masyarakat. Slogan "Saya Indonesia, Saya Pancasila" mampu memberikan sugesti para pengguna media sosial di Indonesia untuk turut serta mengekespresikan nilai-nilai pancasila melalui media sosial yang digunakan.

\section{Referensi}

Amin, M. A. S. (2014). Peran Komunikasi dalam Aktualisasi Status Sosial. JIPSI : Jurnal Ilmu Politik Dan Komunikasi, IV(2), 87-96.

Bungin, B. (2008). Metodologi Penelitian Kualitatif. (B. Bungin, Ed.) (Ed.1-Ke-). Jakarta: Raja Grafindo Persada.

Bungin, B. (2014). Sosiologi Komunikasi. Teori, Paradigm, Dan Diskursus Teknologi Komunikasi Di Masyarakat (Cet. Ke.7). Jakarta: Kencana.

Firdausi, I. A. (2018). Interaksi Remaja Virtual di Media Sosial. Lontar: Jurnal Ilmu Komunikasi, 6(1). Retrieved from ejurnal.lppmunsera.org/index.ph $\mathrm{p} /$ LONTAR/article/view/646\%0 $\mathrm{D}$

Fuqoha, F., Anggraini, A. P., \& Apipah, N. D. (2019). Peningkatan Digital Literasi Terhadap Ujaran Kebencian di Media Sosial melalui Program "Room of Law" Bagi Siswa Sekolah Menengah Atas di Kota Serang. Bantenese Jurnal Pengabdian Masyarakat, 1(1), 9-17. Retrieved from http://e- 
jurnal.lppmunsera.org/index.ph p/PS2PM/article/view/1050

McQuail, D. (2011). Teori Komunikasi Massa McQuail (Ed. 6 Buku). Jakarta: Salemba Humanika. Retrieved from https://it.wikipedia.org/wiki/De nis_McQuail

Pratama, H. N., \& Sadewo, F. S. (2015). Social Networking System Sebagai Public Sphere Politik Era Postdemokrasi Kampanye Pilpres 2014. Jurnal Paradigma, 3(1). Retrieved from https://jurnalmahasiswa.unesa.a c.id/index.php/paradigma/articl e/viewFile/10459/10187.

Rimadi, L. (2017). Slogan Saya Indonesia, Saya Pancasila Dikritik, Ini Kata Barekraf. Retrieved September 20, 2019, from

https://www.liputan6.com/new s/read/2977555/slogan-sayaindonesia-saya-pancasiladikritik-inikata-barekraf

Soekanto, S. (1986). Pengantar Penelitian Hukum (Cet. Ke-3). Jakarta: UI Press.

Soekanto, S. (2007). Sosiologi Suatu Pengantar. Jakarta: Raja Grafindo Persada.

Syarbaini, S. (2001). Pendidikan Pancasila di Perguruan Tinggi. Jakarta: Ghalia Indonesia.

Watie, E. D. S. (2011). Komunikasi dan Media Sosial (Communications and Social Media). Jurnal The Messenger, III(1), 69-75. https://doi.org/10.26623/theme ssenger.v3i2.270
Zulfan, I., \& Gumilar, G. (2014). Potensi Media Sosial Sebaga Sarana Pelestarian Budaya Lokal. JIPSI : Jurnal Ilmu Politik Dan Komunikasi, IV(2), 77-86. Retrieved from jipsi.fisip.unikom.ac.id 